Crawford, J. D., and Kennedy, G. C. (1959). Nature, 183, 891. d'Endocrinologie, 31, 300 .

Edwards, C. R. W. (1970). Proceedings of the Royal Society of Medicine, 64, 32.

Edwards, C. R. W., Chard, T., Kitau, M. J., and Forsling, M. L. (1970). Fournal of Endocrinology, 48, xi.

Edwards, C. R. W., Kitau, M. J., Martin, M. J., and Chard, T. (1972 a). Excerpta Medica International Congress Series, No. 256.

Edwards, C. R. W., Chard, T., Kitau, M. J., Forsling, M. L., and Landon, J. (1972 b). Fournal of Endocrinology, 52, 279.

Golubow, J., Chan, W. Y., and Du Vigneaud, V. (1963). Proceedings of the Society for Experimental Biology and Medicine, 113, 113.

Johnston, C. I. (1972). Fournal of Endocrinology, 52, 69.

Mahon, W. E., Scott, D. J., Ansell, G., Manson, G. L., and Fraser, R. (1967). Thorax, 22, 13 .
Martin, M. J. (1971). Fournal of Endocrinology, 49, 553.

Miller, M., and Moses, A. M. (1970). Endocrinology, 86, 1024

Pepys, J., Jenkins, P. A., Lachman, P. J., and Mahon, W. E. (1965). Fournal of Endocrinology, 33, viii.

Roth, J., Klein, L. A., and Gorden, P. (1968). Excerpta Medica International Congress Series, No. 157.

Scott, A. P., Rees, L. H., Ratcliffe, J. G., and Besser, G. M. (1972). Fournal of Endocrinology, 53, xxxviii.

Snedecor, G. W. (1956). Statistical Methods, 5th edn. Iowa State University Press.

Vavra, I., et al. (1968). Lancet, 1, 948.

Walter, R., and Bowman, R. H. (1973). Endocrinology, 92, 189.

Zaoral, M., and Sorm, F. (1966). Collection of Czechoslovak Chemical Communications, 31, 310 .

Zaoral, M., Kolc, J., and Sorm, F. (1967). Collection of Czechoslovak Chemical Communications, 32, 1250.

\title{
Immediate Sterility after Vasectomy
}

\author{
D. URQUHART-HAY
}

British Medical fournal, 1973, 3, 378-379

\section{Summary}

A 2.5-ml injection of $1 / 1,000$ solution of euflavine given down each vas during vasectomy for sterilization will destroy all sperms within the semen and eliminate the necessity for examining two consecutive specimens of semen for azoospermia after the operation. No local inflammatory response has been observed in the seminal vesicles or prostate of 81 consecutive patients in whom the method has been used.

\section{Introduction}

A disadvantage of vasectomy as a sterilizing procedure is the delay in the semen becoming azoospermic after the operation. A period of two to three months is usual, during which contraceptive precautions must be continued. By destroying the residual sperms with a non-irritant spermicidal solution at the time of division of the vasa it should be possible to overcome this disadvantage and render the semen sterile immediately.

von Friesen (1971) described a method in which a $1 / 1,000$ solution of ethacridine was used, which he claimed would dissolve the sperms in the vas deferens and seminal vesicles.

\section{Method}

Primary vasectomy for the purpose of contraception was carried out on 81 patients on an outpatient basis using local analgesia. Each vas was exteriorized through a separate scrotal incision $1 \mathrm{~cm}$ long and divided. The distal end of each vas was cannulated with a blunt-ended, $2.5 \mathrm{~cm}, 20 \mathrm{G}$ needle attached to a $5 \mathrm{ml}$ plastic syringe containing a sterile solution of $1 / 1,000$ euflavine; $2.5 \mathrm{ml}$ of the solution was injected slowly down each vas. Both proximal and distal ends of each vas were ligated separately by folding each end back on itself and tying each with 00 plain catgut. Plain catgut creates a greater fibrous reaction than the chromicized catgut, and it was felt that this reaction combined with the smooth and rounded contour presented by doubling each vas back on itself would reduce the risk of regeneration to

a minimum. The skin was closed with one suture of 00 plain catgut and a plastic spray dressing applied. Each patient was reviewed at two days and again three months after the procedure.

Examination of the semen was carried out two to 158 days after the operation and as frequently in each patient as he was prepared to allow. Specimens were collected by masturbation and examined immediately in the laboratory or, if preferred, during coitus and brought to the laboratory as quickly as possible thereafter. The interval between ejaculation and examination was one to 110 minutes. Altogether $88 \%$ of the specimens were examined within 30 minutes of ejaculation.

Semen examination was performed by the same technician in all cases. After centrifugation at 2,000 r.p.m. for five minutes a drop of the deposit was examined by light microscopy at $\times 40$. Ten fields were inspected and the number of sperms and the presence or absence of motility noted. Numbers of sperms were recorded as "many" (greater than $20,000,000 / \mathrm{mm}^{3}$ ),

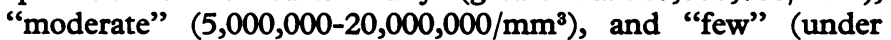
$5,000,000 / \mathrm{mm}^{3}$ ).

\section{Results}

In all 110 specimens of semen examined the sperms were nonmotile. Of these specimens 14 contained many sperms, 8 a moderate number of sperms, and 82 few sperms. Fifty-five of the specimens were collected within 10 days of the vasectomy, 40 between 11 and 50 days, and 10 between 51 and 158 days.

The interval between ejaculation and examination was 1-10 minutes for 54 specimens, 11-20 minutes for 24 specimens, 2130 minutes for 15 specimens, and 31-110 minutes for the remaining 12 specimens.

\section{Discussion}

Persistence of viable sperms in the semen after vasectomy is well. known and most surgeons insist on collecting two consecutive azoospermic specimens of semen some two to three months after the operation before accepting the subject as sterile. Many patients find this onerous, some distasteful, and a few ignore the advice. Sperms will retain their motility in ejaculated semen at room temperature for about 24 hours, but most laboratories will attach significance only to the percentage of motile sperms recorded in specimens examined within four hours of emission. All specimens in this series were examined within two hours of emission.

The acridine derivatives proflavine, acriflavine, aminacrine, ethacridine, and euflavine are slow-acting disinfectants. They 
are bacteriostatic against many Gram-positive bacteria, they inactivate or inhibit some viruses, and their activity is not reduced by tissue fluids or pus. They are used for the treatment of contaminated or suppurative wounds, and have been used in strengths ranging from $0 \cdot 1-0.3 \%$ for the treatment of local infections of the ear, mouth, and throat. Euflavine, which has properties similar to the other acridine derivatives, used in a solution of $1 / 1,000$ is non-irritant and an effective spermicidal. During injection of the solution down each vas most patients experience a sensation in the posterior urethra which many describe as a feeling of wanting to void. A few found this uncomfortable but most made no comment unless asked. The sensation could be reduced and virtually abolished by slow injection of the solution. On voiding after operation the urine is yellow on the first two or three occasions, and the semen is similarly discoloured.

One patient developed haematuria five days after operation. A heavy growth of Escherichia coli was cultured in his urine and it was assumed that the haematuria was a result of this infection.
The infection responded to a course of chemotherapy and there was no recurrence of the bleeding.

Craft and McQueen (1972), in describing the effect of irrigation of the vas on postvasectomy semen counts, suggested that irrigation with a spermicidal preparation might result in a local inflammatory reaction in the seminal vesicles or prostate. This has not been the experience in this series, and the evidence suggests that euflavine used in a $1 / 1,000$ solution has a complete spermicidal action without any irritant side effects. In the light of this experience the method is now used routinely in all vasectomy operations carried out for primary sterilization and it is not considered necessary to examine semen specimens after the procedure to confirm either non-motility of the sperms or azoospermia.

\section{References}

Craft, I., and McQueen, J. (1972). Lancet, 1, 515. von Friesen, B. (1971). Lancet, 1, 598.

\title{
Trial of Chloramphenicol for Meningitis in Northern Savanna of Africa
}

\author{
H. C. WHITTLE, N. McD. DAVIDSON, B. M. GREENWOOD, D. A. WARRELL, A. TOMKINS, \\ P. TUGWELL, A. ZALIN, A. D. M. BRYCESON, E. H. O. PARRY, M. BRUETON, M. DUGGAN, \\ A. D. RAJKOVIĆ
}

British Medical fournal, 1973, 3, 379-381

\section{Summary}

In a controlled trial chloramphenicol proved as effective and much cheaper than penicillin for the treatment of group $A$ meningococcal meningitis in Zaria, Nigeria. A short course of five days cured most patients. Adults and older children were soon able to take chloramphenicol by mouth, which reduced the cost and simplified treatment.

It is suggested that chloramphenicol is a suitable alternative to sulphonamides for the treatment of meningococcal meningitis in those parts of Africa where the organism is sulphonamide-resistant.
Department of Medicine, Ahmadu Bello University, Zaria

H. C. WHITTLE, M.B., M.R.C.P., Lecturer

N. McD. DAVIDSON, B.M., M.R.C.P., Lecturer

B. M. GREENWOOD, M.D., M.R.c.P., Senior Lecturer

D. A. WARRELL, D.M., M.R.C.P., Senior Lecturer

A. TOMKINS, M.B., M.R.C.P., Senior Registrar

P. TUGWELL, M.B., M.R.C.P., Registrar

A. ZALIN, M.B., M.R.C.P., Registrar

A. D. M. BRYCESON, M.D., P.R.C.P., Senior Lecturer

E. H. O. PARRY, M.D., F.R.C.P., Professor

Department of Paediatrics, Ahmadu Bello University, Zaria M. BRUETON, M.R.C.P., D.C.H., Senior Registrar M. DUGGAN, M.R.C.P., D.C.H., Senior Lecturer

Department of Microbiology, Ahmadu Bello University, Zaria A. D. RAJKOVIĆ, M.D., Professor

\section{Introduction}

Every year about 25,000 cases of meningococcal meningitis are reported in epidemics which sweep across the northern savanna of Africa in the dry season (Lapeyssonnie, 1963). In this region long-acting sulphonamides, often given as a single intramuscular dose, have been proved to be a cheap and effective treatment, reducing mortality to about $10-15 \%$ (Lapeyssonnie, 1963). The group A meningococcus, however, which is responsible for these epidemics, has now become resistant to sulphonamides in parts of Africa. In Morocco $90 \%$ of strains isolated from an outbreak were insensitive to sulphadiazine at $10 \mathrm{mg} / \mathrm{l}$. (Sanborn, 1969), in Chad $70 \%$ of strains were resistant to this concentration (Lefèvre et al., 1969), and in Zaria, Nigeria, the figure is $30 \%$ (Sanborn et al., 1973).

An alternative treatment is large and frequent doses of intramuscular penicillin, which has been given to patients with meningococcal meningitis at the Ahmadu Bello University Hospital, Zaria. Though results have been very satisfactory this treatment has not been used elsewhere in the savanna, probably because it is expensive and difficult to administer.

Chloramphenicol is known to be a satisfactory treatment for meningococcal meningitis (McCrumb et al., 1951). Resistant strains seldom develop (Parker et al., 1955; Eickhoff and Finland, 1965) and oral treatment, which is much cheaper than intramuscular penicillin, is also effective (Dean et al., 1953). In Africa chloramphenicol in combination with long-acting sulphonamides (Lefèvre et al., 1969) or with penicillin (Girgis et al., 1972) has been used to treat meningococcal meningitis but its effects alone are not known.

In Zaria, which is in the northern savanna, we have tried chloramphenicol against penicillin in the treatment of meningococcal meningitis to compare their effectiveness and cost when used under local hospital conditions with the aim of 